AGRICULTURE AND BIOLOGY JOURNAL OF NORTH AMERICA

ISSN Print: 2151-7517, ISSN Online: 2151-7525, doi:10.5251/abjna.2013.4.4.358.363

(C) 2013, ScienceHuß, http://www.scihub.org/ABJNA

\title{
Time of planting and weed suppression abilities of some legumes intercropped with maize in the Guinea savanna zone of Ghana
}

\author{
${ }^{1}$ I.Y.D. Lawson, ${ }^{2}$ A. Issahaku, ${ }^{2}$ S. K. Acheampong, ${ }^{2} \mathrm{~B}$. Adams and ${ }^{2} \mathrm{~V}$. Tuffour \\ ${ }^{1}$ Soil Science Department, University of Ghana, Box LG 245, Legon-Accra. \\ ${ }^{2}$ Faculty of Agriculture, University for Development Studies \\ Box TL 1882, Tamale, Ghana.
}

\begin{abstract}
Field experiments were conducted in the field at Nyankpala in the Northern Region of Ghana to determine the appropriate time of intercropping soybean, cowpea and groundnut with maize for optimum yield; and to compare the weed suppression abilities, vis-à-vis maize yields, of these legumes. The legumes were intercropped with the cereal 0, 2 and 4 weeks after planting (WAP) the maize. The intercrop components were arranged in a 1:1 spatial arrangement. The nonintercropped treatments served as sole crops. The experimental plots were laid out in a randomized complete block design (RCBD) with four replications for each treatment. Results showed that leaf area index, shoot biomass, nodule number, pod number, grain yield and land equivalent ratio (LER) decreased with delay in intercropping. However, LER values indicated that the intercrops had yield advantage over the sole crop maize. The appropriate time of intercropping maize with the legumes for optimum maize yield is very early (before or at 2 WAP maize). Results also showed that cowpea suppressed more weeds in the maize field than groundnut and soybean. Cowpea-maize intercrop gave a maize yield of $2988 \mathrm{~kg} / \mathrm{ha}$ which was not significantly different from the sole maize yield of $3291 \mathrm{~kg} / \mathrm{ha}$ at 2 WAP maize.
\end{abstract}

Key words: intercropping, legumes, maize, weed suppression

\section{INTRODUCTION}

Maize is the most commonly cultivated cereal in the northern Guinea savanna of Ghana and according to Dowswell et al. (1996) the crop is cultivated on a million hectare. However, the soils are inherently poor and deficient in organic matter and nutrients, especially $\mathrm{N}$ and $\mathrm{P}$. Besides, marginal lands in northern Guinea savanna agro-ecological areas are brought into cultivation and small-scale farmers are compelled to change from extensive to intensive use of land, without adopting the appropriate management practices.

The intensive cultivation has led to a decrease in soil fertility, build-up of weeds and other pests, and fallow periods have drastically shortened. As a result, soils that were once fertile have become unproductive, severe degradation of the environment has occurred and crop yields are very low. According to Dogbe (1998), one of the consequences of these in northern Ghana in the past few decades has been the falling agricultural productivity index.

One of the coping strategies adopted by farmers in the northern Guinea savanna zone of Ghana is intercropping legumes especially soybean, cowpea and groundnut with maize as a means of securing food in time of crop failure. However, it has been observed that farmers intercrop legumes with maize after the emergence of the cereal at their own convenient time. This implies that there is no uniform time of intercropping the legumes with maize for optimum grain yield. Osei-Bonsu and Buckles (1993) reported that sowing mucuna early could result in reduced maize yield. Kombiok and Clottey (2003) reported that intercropping mucuna with maize at 6 weeks after planting (WAP) maize gave higher maize grain yield than 8 and 10 WAP. Lawson et al. (2007) also reported that intercropping mucuna and canavalia with maize very early (before 6 WAP maize) resulted in maize grain yield losses.

It is in light of this background that the present study called for in-depth look at planting dates of legumes as component crops in a legume-maize intercrop in the northern Ghana. The study was aimed at determining the appropriate time of planting soybean, cowpea and groundnut, and comparing their weed suppression abilities vis-à-vis maize yields as intercrops in maize for optimum grain yield in the northern Ghana. 


\section{MATERIALS AND METHODS}

Experimental site description: The field experiments were conducted at the Faculty of Agriculture Farm, University for Development Studies at Nyankpala in the Northern Region of Ghana for two farming seasons. The area lies within the interior Guinea savanna of Ghana which falls on latitude $9^{\circ} 25^{\prime} 141^{\prime \prime}$, longitude $0^{\circ} 58^{\prime} 142^{\prime \prime}$ and at an altitude of $183 \mathrm{~m}$ above sea level. The area is characterized with natural vegetation dominated by grasses with few shrubs. The area has an average minimum temperate of $25^{\circ} \mathrm{C}$ and maximum average temperature of $35^{\circ} \mathrm{C}$ with total annual monomial rainfall of about $1022 \mathrm{~mm}$. The soil was derived from Voltaian sandstone and classified as Nyankpala series (Plinthic Acrisol; FAO, 1988).

Plant culture: The experimental field was ploughed, harrowed and plots were made. Each plot was $3 \mathrm{~m} x$ $3 \mathrm{~m}$ with $0.5 \mathrm{~m}$ and $1 \mathrm{~m}$ between plots and treatment blocks, respectively. The experimental plots were laid out in a randomized complete block design (RCBD) with four replications for each treatment.

During the first farming season, maize ( Zea mays cv Okomasa) was sown at a spacing of $80 \times 40 \mathrm{~cm}$ and the legumes, soybean (Glycine max cv Anidaso), cowpea (Vigna unguiculata cv Bengpla) and groundnut (Archis hpogeal cv Chinese), were planted at 0,2 and 4 weeks after planting (WAP) the maize. The soybean, cowpea and groundnut were sown at spacings of $80 \times 5 \mathrm{~cm}, 80 \times 40 \mathrm{~cm}$ and $80 \times 30 \mathrm{~cm}$, respectively.

During the second farming season, the maize was sown at a spacing of $80 \times 40 \mathrm{~cm}$ and intercropping was done at 2 WAP the maize to compare the weed suppression abilities of the legumes vis-à-vis maize yields. The legumes were also sown at a spacing of $80 \times 40 \mathrm{~cm}$. The treatments were sole maize $(\mathrm{SM})$, maize-cowpea intercrop $(\mathrm{Cl})$, maize-soybean intercrop (SI) and maize-groundnut intercrop (GI).

The spatial arrangement of the intercrop components was $1: 1$. Non-intercropped plots were made to serve as sole crops. Compound fertilizer, NPK (15-15-15), was applied to the sole maize 4 WAP at $60 \mathrm{~kg} / \mathrm{ha}$ and top-dressed 8 WAP with sulphate of ammonium at 50 $\mathrm{kg} \mathrm{N} / \mathrm{ha}$.

Data collection and analysis: Data on leaf area index (LAI), nodule count and shoot biomass of the legumes were measured at flowering stage. Weed suppression of the legumes was determined at 4,8 and 12 WAP maize. Land equivalent ratio (LER) proposed by Mead and Willey (1980), and maize yield were determined at maturity. Data were subjected to analysis of variance (ANOVA) using the Genstat package, $6^{\text {th }}$ Edition, (Anonymous, 2002). Treatment means were considered to be significantly different at $\mathrm{P} \leq 0.05$.

\section{RESULTS AND DISCUSSION}

Leaf area index: The leaf area index (LAI) measured for the three legumes was in the range of $0.8-2.9$ (Table 1). The LAl decreased with delay in time of intercropping. The sole crops recorded the highest values, however, these values were not significantly $(p>0.05)$ different from legumes intercropped 0 and 2 WAP maize. The present result suggests that as intercropping of the legumes was delayed, the maize developed competitive potential which out-competed the legumes for space and light.

Table 1. Effect of time of intercropping on leaf area index of legumes

\begin{tabular}{|c|c|c|c|}
\hline $\begin{array}{c}\text { Time of } \\
\text { intercropping } \\
\text { (WAP maize) }\end{array}$ & Soybean & Cowpea & Groundnut \\
\hline Sole crop & 2.69 & 1.18 & 2.90 \\
0 & 2.68 & 1.10 & 2.70 \\
2 & 1.80 & 1.01 & 1.40 \\
4 & 1.10 & 0.82 & 0.80 \\
& & & \\
Lsd (5\%) & 0.94 & 0.18 & 1.90 \\
\hline
\end{tabular}

The present result does not differ from the study carried out by Clipson (1994) who reported that taller plants in association with shorter plants alter the rate at which the shorter plants can harvest light energy, and this affects production through reduction in photosynthesis. Singh et al. (1997) reported that when cowpea was intercropped with tall cereal crops, light was an important limiting factor. Singh et al. (1997) also reported that this phenomenon reduced branching due to inadequate light in the late-planted intercrop. Ntare et al. (1993) also suggested that 
reduction of leaf area index in late intercropping of cowpea with cereals occurs because of reduced time of the legumes to develop canopy caused by short photoperiod.

Nodule number: The nodule count decreased with delay in time of intercropping (Table 2). The sole crops recorded the highest values, however, these values were not significantly $(p>0.05)$ different for soybean and groundnut plants intercropped 0 WAP maize. The reduction in nodule number with delayed intercropping could be due to shading effect from the maize. Wahua and Miller (1978) and Eriksen and Whitney (1984) observed that shading by the cereal in an intercrop system reduced biological nitrogen fixation (BNF) of the component legumes; and it is known that number of nodules is a function of BNF. The reduction in nodule number with delay in time of intercropping in the present study could also be due to the fact that the maize plants developed profuse roots with growth period that intertwined with the legume roots such that the maize plant roots might have deceived rhizobia in root adsorption and attachment for infection.

Table 2. Effect of time of intercropping on nodule number

\begin{tabular}{|c|c|c|c|}
\hline $\begin{array}{c}\text { Time of } \\
\text { intercropping } \\
\text { (WAP maize) }\end{array}$ & Soybean & Cowpea & Groundnut \\
\hline Sole crop & 7 & 16 & 107 \\
0 & 6 & 11 & 104 \\
2 & 5 & 10 & 57 \\
4 & 4 & 8 & 53 \\
Lsd (5\%) & 1.85 & 3.27 & 33.10 \\
\hline
\end{tabular}

Shoot biomass: The shoot biomass of the three legumes also decreased with delay in time of intercropping (Table 3). Remarkable decrease in shoot biomass occurred at 2 and 4 WAP maize. Shoot biomass of the sole crops was significantly $(p$ $<0.05)$ higher than that of the intercrops. The present result is in agreement with Osei-Bonsu (1998) who reported that the legume cover crop mucuna gave higher shoot biomass at 4 WAP than 10 WAP maize in a maize-mucuna intercrop trial. The reduction in shoot biomass with delay in intercropping could be due to inadequate interception of sunlight by the legume plants and the reduction in leaf area index with time of intercropping. Singh et al. (1997) reported that when cowpea was intercropped with tall cereal crops, light was an important limiting factor.

Table 3. Effect of time of intercropping on shoot biomass (g/plant) of legumes

\begin{tabular}{|c|c|c|c|}
\hline $\begin{array}{c}\text { Time of } \\
\text { intercropping } \\
\text { (WAP maize) }\end{array}$ & Soybean & Cowpea & Groundnut \\
\hline Sole crop & 56.4 & 19.01 & 63.95 \\
0 & 41.08 & 17.26 & 56.70 \\
2 & 16.56 & 11.30 & 40.05 \\
4 & 15.72 & 7.81 & 29.55 \\
& & & \\
\hline Lsd (5\%) & 4.56 & 1.47 & 5.37 \\
\hline
\end{tabular}

Weed suppression: Results indicated that the legumes suppressed weeds in the maize plots (Table 5). Exner and Cruse (1993) reported that legumes are included in cropping system because they suppress weeds. At 4 WAP only groundnut (Gl) showed significant $(p<0.05)$ decrease in weed biomass. At 8 WAP there was no significant $(p>$ 0.05 ) effect of the legumes on weed biomass. However at 12 WAP, maize plots intercropped with cowpea $(\mathrm{Cl})$ and the sole maize plots $(\mathrm{SM})$ gave the lowest and highest weed biomass, respectively. These two treatments were significantly $(p<0.05)$ different but maize plots intercropped with groundnut (GI) and soybean (SI) were not significantly ( $p$ > $0.05)$ different from the sole maize plots (SM). The 
Agric. Biol. J. N. Am., 2013, 4(4): 358-363

high suppression ability of the cowpea could be due to smoothening ability and early canopy development observed in the field (data not shown). Poku and Akobundu (1983) reported that cowpea developed a competitive canopy early and was able to suppress weed growth.

Table 5. Effect of intercropping on weed biomass $\left(\mathrm{g} / \mathrm{m}^{2}\right)$

\begin{tabular}{|l|c|c|c|}
\hline Treatments & 4 WAP & 8 WAP & 12 WAP \\
\hline Sole & 24.3 & 12.5 & 13.5 \\
SI & 16.4 & 5.9 & 1.5 \\
GI & 17.4 & 6.5 & 8.3 \\
Lsd (5\%) & 12.7 & 9.8 & 5.7 \\
\hline
\end{tabular}

Yield and yield components: Results indicated that the grain yield of the intercropped legumes decreased with delay in time of intercropping (Table 4). The sole legumes recorded the highest grain yield followed by legumes intercropped 0 WAP maize, however, there was no significant $(p>0.05)$ difference between the two treatments. The present study agrees with Nangju (1979) who found that late planting of cowpea in an established maize field resulted in cowpea yield decreases of $58-78 \%$. The reduction in grain yield in the present study could be due to competition for space, light and nutrients. Clipson (1994) reported that taller plants in association with shorter plants alter the rate at which the shorter plants can harvest light energy and this affects production through reduction in photosynthesis. Clipson (1994) also observed that early intercrops perform better because they have a long period of time within which to assimilate organic matter to fill their grains before dry spell sets in.
Table 4. Effect of time of intercropping on grain yield $(\mathrm{kg} / \mathrm{ha})$ of legumes

\begin{tabular}{|c|c|c|c|}
\hline $\begin{array}{c}\text { Time of } \\
\text { intercropping } \\
\text { (WAP maize) }\end{array}$ & Soybean & Cowpea & Groundnut \\
\hline Sole crop & 5208 & 1559 & 2989 \\
0 & 4542 & 1545 & 2426 \\
2 & 4235 & 1101 & 1146 \\
4 & 2876 & 925 & 1066 \\
& & & \\
& & & \\
\hline Lsd (5\%) & 798.9 & 308.1 & 692.2 \\
\hline
\end{tabular}

The sole maize gave higher yield values than that of the intercropped components (Table 5). The comparative low maize grain yield observed for the intercrops as compared with the sole maize could be due to competition for nutrients and other growth factors such as light and space. Wahua (1983) observed that roots of crops in association compete for nutrients and other growth resources, which could negatively affect their development. Results showed that grain yield of maize also decreased with delay in time of intercropping. The present findings does not agree with an earlier work carried out by Lawson et al. (2007) who observed progressive increase in maize grain yield as time of intercropping mucuna and canavalia with maize increased from 0 to 6 WAP maize. The disparity in these findings could be attributed to difference in growth habits of the legumes used. 
Table 5. Effect of time of intercropping on grain yield $(\mathrm{kg} / \mathrm{ha})$ of maize

\begin{tabular}{|c|c|c|c|}
\hline $\begin{array}{c}\text { Time of } \\
\text { intercropping } \\
\text { (WAP maize) }\end{array}$ & Soybean & Cowpea & Groundnut \\
\hline Sole crop & 5240 & 3345 & 3267 \\
0 & 4436 & 3150 & 1533 \\
2 & 3753 & 3145 & 1533 \\
4 & 3500 & 3050 & 1433 \\
Lsd (5\%) & 2144.3 & 629.7 & 672.8 \\
\hline
\end{tabular}

The highest maize grain yield was observed for sole maize (SM) during the second season, however, it was not significantly $(p>0.05)$ different from that of maize-cowpea intercrop $(\mathrm{Cl})$ as shown in Fig. 1. The enhanced maize grain yield of this treatment could be attributed to the high weed suppression ability of the cowpea.

Results also showed that land equivalent ratio (LER) for all the intercrops was $\geq 1.0$ (Tables $6 \& 7$ ). Fussell and Serafini (1985) reported that in an intercropping system the intercrops have yield advantages over the component crops grown as sole crops. Among the legumes cowpea gave the highest LER value during the first farming season. The high LER value suggests beneficial effects of cowpea on the maize crop.

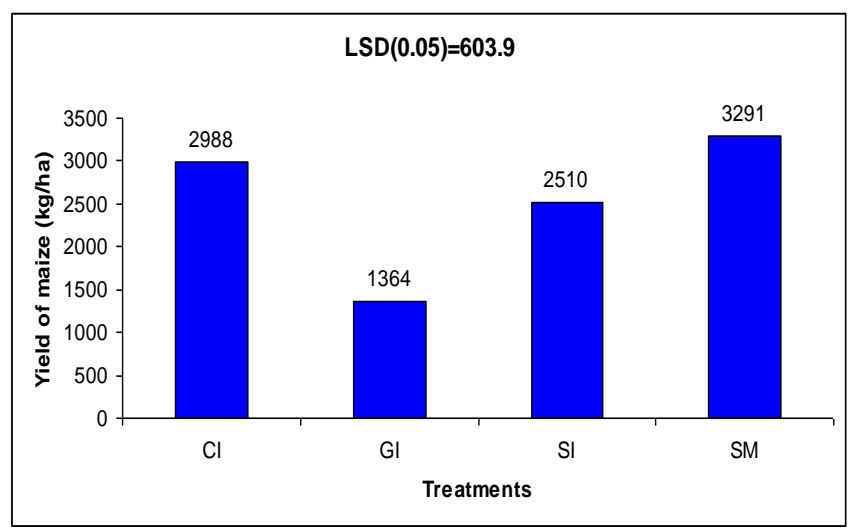

Fig.1. Effect of intercropping on the maize yield during the second season
Table 6. Effect of time of intercropping on Land equivalent ratio during first season

\begin{tabular}{|c|c|c|c|}
\hline $\begin{array}{c}\text { Time of } \\
\text { intercropping } \\
\text { (WAP maize) }\end{array}$ & Soybean & Cowpea & Groundnut \\
\hline 0 & 1.18 & 1.80 & 1.34 \\
2 & 1.18 & 1.60 & 1.19 \\
4 & 1.15 & 1.50 & 1.10 \\
\hline
\end{tabular}

Table 7. Effect of intercropping on Land equivalent ratio (LER) during second farming season

\begin{tabular}{|l|c|c|c|}
\hline Treatments & SI & CI & GI \\
\hline LER & 1.30 & 1.60 & 1.00 \\
\hline
\end{tabular}

\section{CONCLUSION}

The present study revealed that leaf area index, shoot biomass, nodule number, pod number, grain yield and land equivalent ratio (LER) decreased with delay in intercropping. LER values of the intercrops were $\geq 1.0$ which implies that the intercrops had yield advantage over the sole crops. Planting the two intercrop components the same day gave the highest maize grain yield, however, considering the difficulty involved in planting, the appropriate time of intercropping is very early (before or at 2 WAP maize). Comparing the weed suppression abilities of the legumes vis-à-vis maize yield, cowpea suppressed more weeds in the maize field than groundnut and soybean; and cowpea gave the highest maize yield (2988 kg/ha) which was not significantly different from the sole maize yield (3291 $\mathrm{kg} / \mathrm{ha})$. 


\section{REFERENCES}

Anonymous (2002). Genstats package, $6^{\text {th }}$ Edition

Clipson, N.J.W. (1994). Crop productivity. Ed. Weston, G.D., Pub. Butterworth Heinemanm. Pp 19-24.

Dogbe, W. (1998). Green-manure crops for sustainable agriculture in the inland valleys of northern Ghana. In: Cover crops in West Africa contributing to Sustainable Agriculture. IDRC, IITA and Sasakawa Global 2000, Eds. D. Buckles, A. Eteka, O. Osiname, M. Galiba and G. Galiano. Ottawa, Canada. Pp 213-215.

Dowswell, R. L., Christopher, R., Palimal and Roland P. Cantrad (1996). Maize in the Third World. Pp 1-16.

Eriksen, P.I., and Whitney, A.S. (1984). Effects of solar radiation regimes on growth and nitrogen fixation of soybean, cowpea and bushbean. Agronomy Journal 76:529-535.

Exner, D. N., and Cruse R. M. (1993). Interseeded forage legume potential as winter ground cover, nitrogen source and competitor. Journal of Prod. Agric. (ISI) $6: 226-231$

FAO (1988). Soil Map of the World, Revised Legend, Reprinted with corrections. World Soil Resources Report 60, FAO, Rome.

Fussell, L.K. and Serafini, P.G. (1985). Crop association in the semi-arid tropics of West Africa: Research strategies; past and future. In: Appropriate technologies for farmers in semi-arid West Africa. Eds Wiohm and Navy, G.J. University of Purdue, West Lafayette. Pp 218-235.

Kombiok J.M. and V.A. Clottey (2003). Maize yield and soil $\mathrm{N}$ as affected by date of planting mucuna in maizemucuna intercropping in Ghana. Tropical Agriculture (Trinidad) 80: 77-82.

Lawson, I.Y.D., I.K Dzomeku and Y. J. Drisah (2007). Time of planting mucuna and canavalia in an intercrop system with maize. Journal of Agronomy. 6(4):534540.

Mead, R. and R.W. Willey (1980). Designing experiments for intercropping research. Exp. Agric. 16:329-342

Nangju, D. (1979). Effects of density, plant type and season on growth and yield of cowpea. Journal of the America Soc. of Hort. Sci. 104:466-470

N'tare, B.R, Williams, J.H. and Bationo, C. (1993). Physiological determinants of cowpea seed yield as affected by phosphorus fertilizer and sowing dates in intercrop with millet. Field Crops Research 35: 151-158

Osei-Bonsu, P., and Buckles, D. (1993). Controlling weeds and improving soil fertility through the use of cover crops: experience with Mucuna spp. in Benin and Ghana. West African Farming Systems Research Network Bulletin 14:2-7

Osei-Bonsu, P. (1998). On-farm trials of Mucuna spp. in Ghana (Abstract). In: Cover Crops in West Africa Contributing to Sustainable Agriculture. IDRC, IITA and Sasakawa Global 2000, Eds. D. Buckles, A. Eteka, O. Osiname, M. Galiba and G. Galiano. Ottawa, Canada. Pp 201-202.

Singh, B.B.; D.R. Mohan Raj, K.E. Dashiell and L.E.N. Jackai (1997). Advances in Cowpea Research. Published by International Institute for Tropical Agriculture, Ibadan, Nigeria and Japan International Research Centre for Agricultural Science, Tsukuba, Ibaraki, Japan. Pp11-217.

Wahua, T.A. and Miller, D.A. (1978). Effects of shading on nitrogen fixation, yield and plant composition of fieldgrown soybean. Agronomy Journal 70: 387-392

Wahua, T.A.T. (1983). Nutrient uptake by intercropped maize and cowpea and a concept of nutrient supplementation index. Experimental Agric. 19:263275. 